\title{
KARAKTERISTIK FISIK SERBUK EKSTRAK BUNCIS (Pheseolus vulgaris L) DENGAN VARIASI LAMA PENYIMPANAN
}

\author{
Rizki Nugrahani ${ }^{1}$, Yayuk Andayani² dan Aliefman Hakim² ${ }^{2}$ \\ 1 Prodi Farmasi (D3), Fakultas ilmu Kesehatan Universitas Nahdlatul Wathan Mataram \\ 2Program Studi Magister Pendidikan IPA, Program Pascasarjana Universitas Mataram \\ *Penulis Korespondensi. Email: rizkinugrahani083@gmail.com
}

\section{ABSTRAK}

Telah dilakukan penelitian tentang analisis sifat-sifat fisik serbuk ekstrak buncis (Phaseolus vulgaris L). Penelitian ini bertujuan untuk mengetahui bagaimana karakter fisik dari serbuk ekstrak buncis yang telah di simpan dalam variasi waktu yang telah ditentukan. sifat fisik yang diuji meliputi kadar air, kelarutan dan uji organoleptik. Hasil uji kadar air sampel dengan variasi penyimpanan kurang dari 1, 1, 2 dan 3 bulan bertut turut yaitu 5,55\%, 2,86\%,3,83\% dan $3,54 \%$ serta kelarutannya sebesar $42,67 \%, 33,84 \%, 44,51 \%$ dan 34,33\% untuk pelarut Artificial Gastrid Fluida (AGF) dan 31,79\%, 35,08\%, 43,24 dan 34,52\% untuk pelarut Air. Hasil pengujian organoleptik diketahui bahwa warna sampel serbuk ekstrak buah buncis dengan waktu penyimpanan \pm 2 bulan paling disukai oleh panelis, sampel segar memiliki nilai rata-rata tertinggi untuk rasa dan aroma, sedangkan tekstur sampel panelis lebih menyukai sampel yang sudah disimpan selama \pm 3 bulan.

Kata Kunci:

Karakterisitik; Fisik; Ekstrak buncis; Lama Penyimpaan

$\begin{array}{lcc}\text { Diterima: } & \text { Disetujui: } & \text { Online: } \\ \text { 4-02-2020 } & 19-02-2020 & 1-03-2020\end{array}$

\section{ABSTRACT}

Research has been carried out on the analysis of physic properties of green bean extract powder (Phaseolus vulgaris L). This study aims to determine the physical characteristics of the bean extract powder that has been stored in a predetermined time variation. The physic properties tested included water content, solubility and organoleptic tests. The results of the sample water content test with storage variations of less than 1, 1, 2 and 3 months respectively were $5.55 \%, 2.86 \%, 3.83 \%$ and $3.54 \%$ and the solubility was $42.67 \%, 33,84 \%, 44.51 \%$ and $34.33 \%$ for Artificial Gastrid Fluid (AGF) solvents and $31.79 \%, 35.08 \%, 43.24$ and $34.52 \%$ for Water solvents. The results of the organoleptic test showed that the color of the bean extract powder sample with a storage time of \pm 2 months was the most preferred by the panelists, Fresh samples had the highest average scores for taste and aroma, of the panelist samples preferred the samples that had been stored for \pm 3 months

Copyright $@ 2021$ Jsscr. All rights reserved

Keywords:

Characteristics; Physical; Bean Extract; Long Storage Time

Received:

2020-02-4
Accepted:

2020-02-19
Online:

2020-03-1 


\section{Pendahuluan}

Indonesia yang terletak di wilayah tropis memiliki kekayaan alam yang melimpah. Terdapat kurang lebih dari 7000 spesies tumbuhan (90\%dari spesies tumbuhan Asia) diketahui berkhasiat sebagai tanaman obat [11]. Sebagian besar tumbuhan tersebut telah dimanfaatkan oleh penduduk lokal sebagai bahan obat-obatan tradisional, namun belum diusahakan secara optimal untuk pengembangan obat yang memberikan nilai ekonomis sehingga dapat menjadi sumber pendapatan bagi penduduk.

Harga beberapa obat-obatan modern sangat mahal. hal tersebut dikarenakan seluruh bahan baku obat- obatan modern tersebut merupakan bahan impor. Kondisi ini mendorong masyarakat kembali menggunakan pengobatan tradisional atau alternatif. Obat merupakan komponen penting dalam sistem pelayanan kesehatan nasional, termasuk sediaan farmasi berbasis tanaman obat (obat herbal). Tiga kategori sediaan farmasi berbasis tanaman obat, yaitu jamu, obat herbal terstandar dan fitofarmaka. Seperti halnya dengan kebutuhan obat konvensional, prediksi kebutuhan obat herbal ditentukan oleh 2 faktor utama, yaitu perkembangan demografi dan perkembangan pola penyakit [5].

Obat tradisional telah diterima dengan baik hampir di seluruh negara di dunia, baik di negara berkembang maupun negara maju [6]. Produksi obat tradisional dari tahun ke tahun juga mengalami peningkatan karena banyaknya variasi sediaan bahan alam, maka untuk memudahkan pengawasan dan perizinan, Badan Pengawasan Obat dan Makanan mengelompokkan obat tradisional dalam sediaan jamu, obat herbal terstandar, dan fitofarmaka [6]. Obat tradisional tersedia dalam bentuk yang dapat diminum atau hanya ditempelkan pada kulit. tidak tersedia dalam bentuk suntikan atau aerosol. Bentuk sediaan obat- obat tradisional dapat berupa serbuk yang menyerupai bentuk sediaan obat modren, kapsul, tablet, larutan, ataupun pil.

Penelitian mengenai bahan obat tradisional sudah banyak dikembangkan oleh lembaga pemerintah dan profesi untuk mencari lebih banyak lagi potensi sumber daya alam yang terdapat di indonesia terutama di bidang fitofarmaka. Salah satu jenis tanaman yang memiliki potensi sebagai bahan obat tradisional yaitu buncis. Tanaman buncis merupakan tanaman yang memiliki manfaat bagi kesehatan karena mengandung protein tinggi, serat, prebiotik, vitamin B dan terdapat beragam mikronutrien kimia yang berkhasiat untuk mengobati berbagai jenis penyakit [2]. Tanaman buncis diketahui memiliki kandungan senyawa antioksidan [9], $\beta$-sitosterol dan stigmasterol [8]. Dalam pengobatan tradisional, tanaman buncis telah digunakan sebagai obat antihipolikenik dan sumber serat yang dapat memperlancar pencernaan $[2,13]$.

Merujuk pada efek farmakologi yanag dimiliki oleh tanaman buncis maka tanaman buncis dapat diolah menjadi bahan baku pembuatan obat herbal atau sering disebut obat fitofarmaka atau obat tradisional. Obat tradisional yang beredar dan digunakan masyarakat Indonesia sebagian besar merupakan hasil standar produk konsumsi tidak berdasarkan hasil standardisasi farmasitikal. Departemen kesehatan telah membuat aturan supaya pengembangan obat tradisional dapat dipertanggung jawabkan secara ilmiah. Pengembangan obat tradisional harus memenuhi beberapa tahap yaitu seleksi, penyaringan zat biologik, pengujian farmako-dinamik, pengujian toksisitas, pengembangan sediaan formulasi obat, dan pengujian klinik pada manusia. Penelitian sebelumnya membuktikan bahwa semakin lama penyimpanan dan semakin tinggi suhu 
penyimpanan menyebabkan peningkatan kadar air serta penurunan kadar antioksidan kelarutan serbuk Cinna-Ale instan selama penyimpanan [7].

Beberapa karakter fisik yang menjadi salah satu standar penting selain beberapa standar lainnya seperti yang harus diperhatikan adalah kelarutan, kadar air, bau, rasa, warna dan tekstur sediaan yang menjadi bahan baku obat tradisional golongan fitofarmaka. Dimana obat fitofarmaka adalah produk yang mengandung bahan atau ramuan bahan yang berupa bahan tumbuhan, bahan hewan, bahan mineral, sediaan sarian (galenik) atau campuran dari bahan tersebut yang telah dibuktikan keamanan dan khasiatnya secara ilmiah dengan uji praklinik dan uji klinik serta bahan baku dan produk jadinya telah distandardisasi $[3,14]$.

Evaluasi sensori atau organoleptik merupakan cara analisis karakteristik fisik menggunakan indera manusia untuk mengukur tekstur, penampakan, aroma dan flavor produk pangan. Penerimaan konsumen terhadap suatu produk diawali dengan penilaiannya terhadap wuud produk, rasa dan bagaimana tekstur dari produk tersebut. Tujuan dari pengujian organolepti adalah untuk mengetahui bagaimana tanggapan dan penerimaan konsumen, uji organoleptik yang menggunakan panelis (pencicip yang telah terlatih) dianggap yang paling peka. sehingga sering digunakan dalam menilai mutu berbagai jenis makanan maupun produk untuk mengukur daya simpannya atau dengan kata lain untuk menentukan tanggal kadaluwarsa makanan. Pengujian dengan metode organoleptik dianggap paling praktis lebih murah biayanya. Melengkapi informasi manfaat penggunaan tanaman buncis dibidang fitofarmaka, perlu dilakukan Penelitian eksperimental ini yang bertujuan untuk mengetahui karakteristik fisikokimia serbuk ekstrak buncis sebagai bahan obat tradisional

\section{Metode}

Analisis karakteristik fisik pada penelitian ini terdiri dari tiga tahap pengujian yaitu uji kadar air dan uji kelarutan dan pengujian mutu organoleptik. Pengambilan data uji organoleptik menggunakan uji hedonik, sedangkan untuk uji kadar air dan kelarutan menggunakan metode gravimetri. Bahan yang digunakan dalam penelitian ini yaitu serbuk ekstrak buncis (Phaseolus vulgaris L.) yang di dapatkan dari indutri obat tradisional yang terdapat di wilayah kota mataram, aquades, pelarut AGF (Artificial Gastrid Fluida), roti tawar. Alat yang digunakan antara lain oven, kertas saring, timbangan analaitik, alat gelas, desikator, pompa vakum, fortex, aluminium foil, kuisioner uji hedonik.

\section{a. Penentuan Kadar Air}

Sebanyak 1 gr sampel serbuk $P$ Vulgaris $L$. dimasukkan kedalam cawan porselin yang sudak dikeringkan didalam oven pada suhu $105{ }^{\circ} \mathrm{C}$ selama 30 menit. Cawan porselin kemudian ditimbang untuk mengetahui berat cawan kosong. Sampel diletakkan didalam cawan kemudian dikeringkan dalam oven pada suhu $105{ }^{\circ} \mathrm{C}$ selama 3 jam, kemudian didinginkan didalam desikator, lalu ditimbang bobotnya. Penimbangan dilakukan sampai memperoleh bobot tetap (konstan).

b. Uji kelarutan

Besarnya nilai kelarutan serbuk ekstrak $P$ Vulgaris L. dapat dihitung dengan cara gravimetri. Menurut [1] Sebanyak 1 gr sampel ditimbang kemudian dilarutkan dalam $150 \mathrm{ml}$ pelaarut Air dan Artificial Gastrid Fluida (AGF), larutan di fortex selama \pm 1 menit , kemudian disaring menggunakan kertas saring whatman no.42 dengan bantuan 
pompa vakum. Sebelum digunakan kertas saring dikeringkan terlebih dahulu dalam oven pada suhu $105{ }^{\circ} \mathrm{C}$ selama 30 menit, dibiarkan dalam desikator dan ditimbang. Setelah penyaringan, kertas saring dan residu dikeringkan dalam oven pada suhu 105 ${ }^{\circ} \mathrm{C}$ selama 3 jam, dibiarkan dalam desikator dan ditimbang .

$$
\text { kelarutan }(\%)=100-\frac{(a-b)}{(100-d / 100) \times c} \times 100 \%
$$

Keterangan : $\quad \mathrm{a}=$ berat kertas saring + residu $(\mathrm{gr})$

$\mathrm{b}=$ berat kertas saring kering (gr)

$\mathrm{c}=$ berat sampel awal (gr)

$\mathrm{d}=$ kadar air sampel $(\% \mathrm{bb})$

\section{c. Uji Organoleptik}

Parametik sensorik serbuk ekstrak buah buncis diuji menggunakan uji kesukaan atau uji rating hedonik terhadap warna, rasa, bau dan tekstur. Pengujian ini dilakukan berdasarkan pengamatan panca indera panelis dan bersifat subyektif (berbeda-beda setiap individu). Uji rating kesukaan dilakukan oleh 36 orang panelis konsumen. Sampel yang diberikan kepada panelis yaitu serbuk ekstrak buncis yang telah disimpan dengan variasi waktu kurang dari 1 bulan, \pm 1 bulan, \pm 2 bulan, \pm 3 bulan. Sampel diberikan kode yaitu A0, A1, A2, A3 yang kemudian diberikan kepada panelis secara bersamaan. Panelis terlebih dahulu akan membaca informasi yang terdapat pada lembar kuisioner. Penilaian panelis terhadap warna, rasa, bau dan tekstur dituliskan dalam skala hedonik 0-5 dengan tingkat kesukaan yang semakin meningkat. Skala tingkat kesukaan yang digunakan adalah 0) tidak suka, 1) netral, 2) agak suka, 3) suka, 4) sangat suka 5) amat sangat suka.

3. Hasil dan Pembahasan

Uji fisikokimia terhadap kadar air, uji kelarutan dan uji organoleptik bertujuan untuk mengetahui karakteristik fisik sampel yang digunakan. Hasil uji kadar air dan kelarutan ditunjukkan pada Tabel 1.

Tabel 1. Hasil Uji Kadar Air dan Kelarutan

\begin{tabular}{cccc}
\hline $\begin{array}{c}\text { Waktu } \\
\text { penyimpanan } \\
\text { (Bulan) }\end{array}$ & $\begin{array}{c}\text { Kadar Air } \\
\mathbf{( \% )}\end{array}$ & \multicolumn{2}{c}{$\begin{array}{c}\text { Kelarutan } \\
(\mathbf{\%})\end{array}$} \\
\cline { 3 - 4 } < $\mathbf{1}$ bulan (segar) & 5.58 & 42,65 & Air \\
$\mathbf{1}$ bulan & 2.88 & 33,83 & 31,77 \\
$\mathbf{2}$ bulan & 3.91 & 44,48 & 43,06 \\
$\mathbf{3}$ bulan & 3.58 & 34,30 & 34,49 \\
\hline
\end{tabular}

Evaluasi fisik yang pertama dilakukan adalah uji kadar air yang bertujuan untuk menentukan kadar air yang terkandung dalam serbuk sampel. Kandungan air diperoleh dengan cara menghitung persentase kadar air dalam serbuk dengan metode gravimetri. Kadar air yang rendah baik untuk penyimpanan sediaan dalam jangka waktu yang lebih lama, sedangkan kadar air yang tinggi merupakan media yag baik untuk pertumbuhan mikroorganisme seperti jamur, dimana mikroorganisme dapat tumbuh baik dengan kadar air diatas $10 \%$. Dari hasil evaluasi kadar air rata-rata untuk masing-masing sampel 
diperoleh nilai dibawah 10\% (Tabel 1). Dari hasil tersebut diketahui bahwa semua sampel memenuhi syarat standar Peraturan Kepala Badan Pengawas Obat dan Makanan no 12 tahun 2014. Kadar air tertinggi pada sampel yang disimpan kurang dari 1 bulan sedangkan kadar air terendah pada sampel yang disimpan selama \pm 1 bulan. Lama penyimpanan sampel diketahui berpengaruh terhadap nilai kadar air setelah serbuk ekstrak diproduksi, nilai kadar air sampel segar lebih besar dibandingkan setelah dilakukan proses penyimpanan [4].

Evaluasi yang ke dua adalah kelarutan serbuk sampel dalam dua pelarut yang berbeda yaitu pelarut air yang mewakili kelarutan bahan di luar tubuh dan Artificial Gastrid Fluida (AGF) yang mewakili kelarutan dalam tubuh. Dari data hasil penelitian (Tabel 1)diperoleh nilai yang tidak berbeda jauh antara kelarutan pada air dan AGF namun memiliki persamaan pada sampel yang memiliki kelarutan tertinggi yaitu pada sampel dengan penyimpanan \pm 2 bulan, hal tersebut dipengaruhi oleh ukuran butiran serbuk yang sangat lembut / granul halus jumlahnya banyak dibanding tiga sampel lainnya. Ukuran butiran yang halus memiliki luas permukaan yang lebih besar dengan demikian kemungkinan terjadinya reaksi antara pelarut dan zat terlarut semakin besar.

Pemeriksaan organoleptik menunjukkan Aroma yang khas dari serbuk ekstrak buncis yang telah mengalami pengeringan pada suhu tinggi yaitu aroma gosong. Aroma semua sampel hampir sama hanya terdapat perbedaan ketajaman aroma yang kemungkinan dipengaruhi oleh lama penyimpanan. Semakin lama umur penyimpanan ketajaman aromanya semakin berkurang. Aroma merupakan pencicipan jarak jauh karena manusia dapat mengenal rasa dari makanan yang belum terlihat hanya dengan mencium aromanya, manusia dapat mencium bau yang keluar dari bahan makanan karena adanya sel-sel epitel alfaktori dibagian dinding atas rongga hidung [10,15]. Warna menunjukkan sedikit perbedaan namun tidak mencolok dikarenakan sampel memiliki tanggal produksi yang berbeda sehingga kemungkinan perbedaan bahan yang digunakan mempengaruhi warna yang muncul begitupun dengan tekstur serbuk setiap variasi sampel dengan waktu produksi yang berbeda memiliki ukuran butiran serbuk yang bervariasi. Sedangkan untuk rasa, semua sampel memiliki rasa yang sama yaitu rasa pahit. 


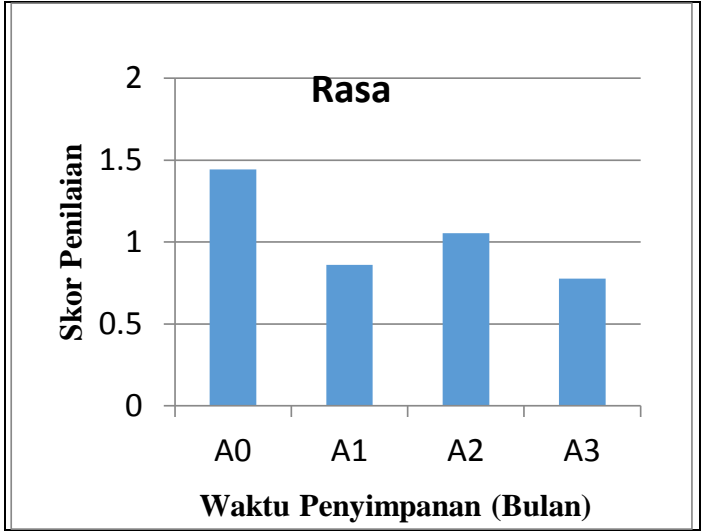

(a)

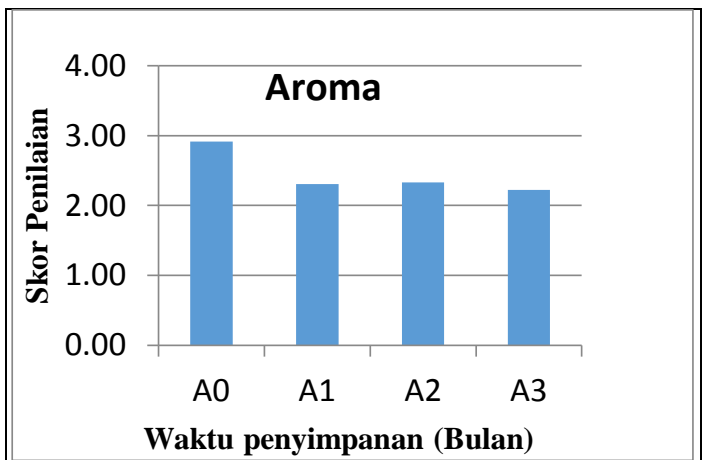

(c)

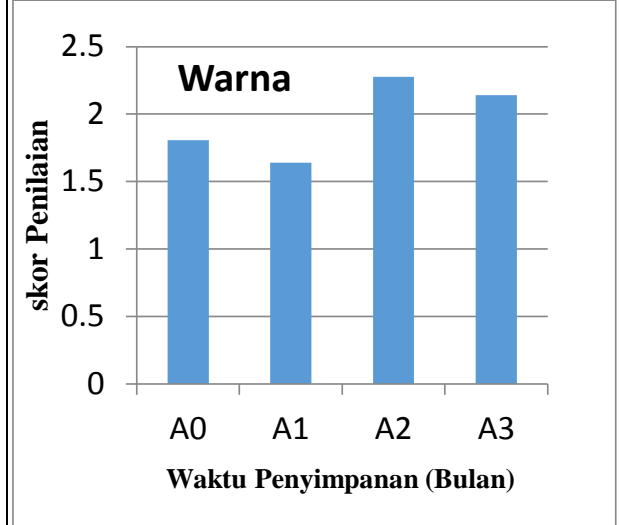

(b)

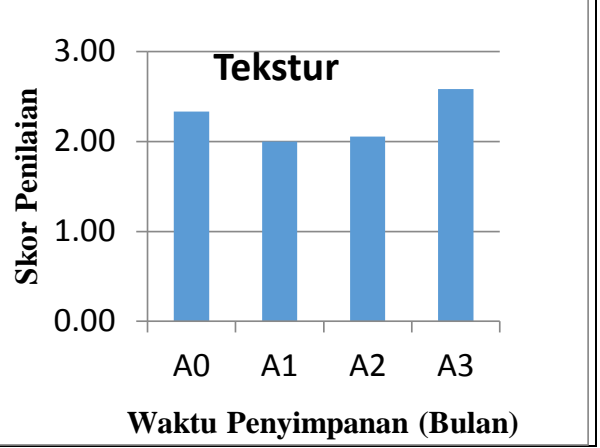

(d)

Gambar 1. Hasil uji organoleptik

Untuk nilai uji hedonik diperoleh nilai rata-rata untuk warna menunjukkan sampel yang sudah disimpan \pm 2 bulan yang lebih disukai dibanding warna sampel yang lain (Gambar 1a), untuk rasa dan aroma sampel segar (kurang dari 1 bulan) lebih disukai oleh panelis dibanding tiga sampel lainnya (Gambar 1a dan 1c), sedangkan untuk tekstur sampel, sampel yang sudah disimpan \pm 3 bulan lebih disukai oleh panelis karena memiliki nilai rata-rata tertinggi diantara tiga sampel lainnya (Gambar 1d) .

Stabilitas sediaan farmasi merupakan salah satu kriteria yang amat penting untuk suatu hasil produksi yang baik. Ketidakstabilan produk obat dapat mengakibatkan terjadinya penurunan sampai dengan hilangnya khasiat obat, obat dapat berubah menjadi toksik atau terjadinya perubahan penampilan sediaan (warna, bau, rasa, konsistensi). Ketidakstabilan suatu sediaan farmasi dapat dideteksi melalui perubahan sifat fisika dan kimia. Stabilitas obat dapat diketahui dari ada atau tidaknya penurunan kadar selama penyimpanan $[12,16]$. Faktor lingkungan seperti temperatur, radiasi cahaya dan udara (khususnya oksigen, karbon dioksida dan uap air) juga mempengaruhi stabilitas. Demikian pula faktor formulasi seperti ukuran partikel, $\mathrm{pH}$, sifat dari air dan sifat pelarutnya dapat mempengaruhi stabilitas [12].

\section{Kesimpulan}

Uji organoleptik menunjukkkan warna sampel serbuk ekstrak buah buncis dengan waktu penyimpanan \pm 2 bulan paling disukai oleh panelis. Sampel segar lebih disukai oleh panelis untuk rasa dan aroma sampel, sedangkan tekstur sampel panelis lebih menyukai sampel yang sudah disimpan \pm 3 bulan. Kadar air semua sampel serbuk 
ekstrak buah buncis memenuhi standar yang ditentukan yaitu dibawah 10\%. Nilai kelarutan sampel terhadap pelarut Artificial Gastrid Fluida (AGF) dan pelarut air menunjukkan nilai yang hampir sama yaitu 33\%-45\% untuk AGF dan 31-43\% untuk air.

\section{Referensi}

[1]. AOAC. 1999. Official Methods of Analysis (15th Ed.). K. Helrich (Ed.). Virginia.

[2] Batalla., Widholm., fahey., Tostado., Lopez. 2006. Chemical Components with Health Implications in Wild and Cultivated Mexican Common Bean Seeds (Phaseolus vulgaris L.). Jurnal Agricultural And Food Chemistry. 54: 2045-2052.

[3] BPOM. 2019. Peraturan Badan Pengawas Obat dan Makanan Nomor 32 Tahun 2019 Tentang Persyaratan Keamanan dan Mutu Obat Tradisional.

[4] BPOM . 2014. Peraturan Badan Pengawas Obat dan Makanan Nomor 122014 Tahun Persyaratan mutu Obat Tradisional

[5] BPPT. 2017. Outlook Teknologi Kesehatan, Teknologi Untuk Industri Bahan Baku dan Obat Herbal Proyeksi 2035. BPPT Press

[6] Dewi,R.S., Wahyuni., Pratiwi ,E., Muharni, S. 2019. Penggunaan Obat Tradisional oleh Masyarakat di Kelurahan Tuah Karya Kota Pekanbaru. Jurnal Penelitian Farmasi Indonesia 8(1).

[7] Edria, D. 2010. Penentuan Umur Simpan Minuman Fungsional Cinna-Ale Instan dengan Metode Arrhenius. Skripsi. Fakultas Teknologi Pertanian Institut Pertanian Bogor.

[8] Jannah, H., Sudarma., Andayani, Y. 2013. Analisis Senyawa Fitosterol Dalam Ekstrak buah Buncis (Phaseolus vulgaris L.). Program Pascasarjana, Universitas Mataram.

[9] Kurnia, N. 2013. Uji Aktivitas Antioksidan Ekstrak Air Buah Buncis (Pheseolus vulgaria L.). Tesis S2. Universitas Mataram

[10] Montolalu, S., Lontaan, N., Sakul, S., dan Mirah. 2013. Sifat Fisiko-Kimia dan Mutu Organoleptik Bakso Broiler dengan Menggunakan Tepung Ubi Jalar (Ipomoea Batatas L). Jurnal Zootek, Vol.32 No.5.:

[11] Nurdin., Clara M,. Kusharto., Tanziha Ikeu., dan Januwati. 2009. Kandungan Klorofil Berbagai Jenis Daun Tanaman dan Cu-Turunan Klorofil serta Karakteristik Fisiko-Kimianya. Jurnal Gizi dan Pangan, 4(1): 13 - 19

[12] Pratiwi. L., Fudholi.A., Martien. R., Pramono. S. 2018. Uji Stabilitas Fisik dan Kimia Sediaan SNEDDS (Self-nanoemulsifying Drug Delivery System) dan Nanoemulsi Fraksi Etil Asetat Kulit Manggis (Garcinia mangostana L.). Traditional Medicine Journal. Vol. 23(2). 
[13] Micheli, L., Lucarini, E., Trallori, E., Avagliano, C., De Caro, C., Russo, R., ... \& Di Cesare Mannelli, L. (2019). Phaseolus vulgaris L. Extract: alpha-amylase inhibition against metabolic syndrome in mice. Nutrients, 11(8), 1778.

[14] Romero del Castillo, R., Costell, E., Plans, M., Simó, J., \& Casañas, F. (2012). A standardized method of preparing common beans (Phaseolus vulgaris L.) for sensory analysis. Journal of sensory studies, 27(3), 188-195.

[15] Abu-Reidah, I. M., Arráez-Román, D., Lozano-Sánchez, J., Segura-Carretero, A., \& Fernández-Gutiérrez, A. (2013). Phytochemical characterisation of green beans (Phaseolus vulgaris L.) by using high-performance liquid chromatography coupled with time-of-flight mass spectrometry. Phytochemical Analysis, 24(2), 105116.

[16] Ramadhani, U. P., Chandra, B., \& Rivai, H. (2020). Overview of phytochemistry and pharmacology of chickpeas (Phaseolus vulgaris). World Journal of Pharmacy and Pharmaceutical Sciences, 9(9), 442-61. 